\title{
Neo-Vedantism in the Bengal Renaissance: Genesis, Foundations and Development in XIX Century*
}

\author{
Tatiana Skorokhodova \\ Department 'Theory and Practice of Social Work' \\ Penza State University \\ Penza, Russia \\ E-mail: skorokhod71@mail.ru
}

\begin{abstract}
The article represents genesis and development of Neo-Vedanta philosophy by thinkers of Bengal Renaissance thinkers. The reconsideration of classical Vedanta is described as continuation of its ideas as most suitable for Modern needs in cultural spheres as well as re-building of these ones based on humanistic approach.
\end{abstract}

Keywords-Modern Indian philosophy; Neo-Vedanta; the Bengal Renaissance

\section{INTRODUCTION: ORIGIN OF NEO-VEDANTISM}

Development of Indian philosophy in Modernity connected with socio-cultural processes of Indian-Western dialogue in colonial period. These ones had generated intensive reconsiderations of native Indian heritage of thought and practice in comparison with the Western culture. Generally, Modern Indian philosophy indebted for its origin to intellectual and reformist activity of the Indian Renaissance personalities. The Indian Renaissance was the epoch of socio-cultural renascence in different regions of British India. It was a complex of intellectual, socio-practical and cultural transformations in traditional society, which began to include in Modern world [See: 1;2]. This complex had been firstly, created in Bengal - the most developed of colonial India provinces situated on a far periphery of traditional society and turned in a meeting-point of the West and the East. The Bengal Renaissance was the core of the Indian Renaissance in religious, philosophical, social, political, literary and art movements and achievements [See: $3 ; 4 ; 5 ; 6]$. It were Bengal intellectuals who began to create new philosophy in India. The most influential and respected philosophical tradition in Modern India have been recognized Vedanta or, more correctly, its new version called Neo-Vedantism. In XIX century Bengal intellectuals had made choice of Vedanta, from all multiplicity of Indian traditional schools.

Why had Bengal thinkers made a choice of Vedanta? An answer lays in a broad cultural context of Indian-Western interaction in a sphere of thought. The main problem for

*The study is supported by Russian Science Foundation grant "Indian Philosophy in the History of World Philosophy Context: the Meanings' Translation Problem", project No 16-18-10427. thinkers from Rammohun Roy (1772-1833) to Rabindranath Tagore (1861-1941) was a searching for indigenous cultural basis of India's development in Modernity. The basis ought to serve a renovation of society and culture as well as understanding and adoption of key Western achievements. In other words, it ought to be the base of Indian-Western synthesis in thought and culture. From the intention appeared philosophizing of spiritual, moral and social-political problems in Indian mind and life of people.

The present condition of Indian society - especially of Hindu community - in colonial situation was considered by Bengal thinkers as serious decline in comparison with dynamic development of the West. The first reformer and philosopher of Modern India Rammohun Roy had connected this decline with 'Hindu idolatry' and its antihuman practice - burning widows, infanticide, child marriage, polygamy - and superstitions; he estimated ones as "...the moral debasement of a race who... are capable of better things; whose susceptibility, patience, and mildness of character, render them worthy of a better destiny" [7, P. 74]. Rammohun had seen the reasons of the condition first of all in spiritual sphere, in religious consciousness of his coreligionists.

Bengal thinkers' striving to elevate the spiritual sphere of society can be explained by influence of many factors. They had an experience of contemplation and understanding of Other religions (Christianity and Islam) along with their own Hindu faith. The brightest example of one is Rammohun Roy, who was brought up in Vaishnav family and in early childhood was very devout $[8$, P. 5]. Owing to his Islamic education in Patna, he had the experience of contemplation of the other religion. Then he was impressed by Christianity and had studied the Bible. The preference of monotheism as base of any religion helps him to create the idea of Hinduism as monotheistic religion [See: 4, P. 39-71]. In Bengal thinkers' consciousness had been built the triple dialogue of religions, what helped to create an attractive image of Hinduism and Indian culture, as well as to create general universalist approach in NeoVedantism. Moreover, Bengal thinkers had been influenced by traditional Sanskrit and Modern English educations. Sanskrit education gave the knowledge of Scriptures and philosophical 
heritage, English one offered modern patterns of thinking and acting along with European thought heritage. The special factor was European Oriental studies in Indian culture and history, especially, Indian antiquity [See: 4, P. 7-38; 5]. Both traditional education and European's interest to Indian culture had stimulated a process which J. Nehru later described as 'Discovery of India' by her own intellectuals.

The intellectuals' need for authoritative support in Hindu tradition had motivated to find the sacred texts as grounding of religious, moral and social novation. But the tradition of Hinduism was many-sided and broad. It put the question of choice from texts and traditions the most adequate for the support to novations and reforms. Searching for the textual support, Rammohun Roy and his adherents and spiritual heirs turned to the heritage of Indian 'Axial age' (K. Jaspers), viz. the Upanișads, then Bhagavadgita and Badarayana's Vedantasutra. Particularly, it was the discovery of basic philosophical ideas of Vedanta as 'end of Vedas' (Upanișads) as well as orthodox dārșana with its ideas of Brahman-atman (soul) identity, anti-ritualism and path of knowledge for liberation.

Bengal thinkers have made the choice of Vedanta from orthodox schools, because unorthodox (nastika) dārșanas were not suitable for modern practical purposes. From orthodox dārșanas nyāya dominated in thinking of orthodox Brahmins, and in scholastic of Bengal, as well its pair Vaiśeșika. Sānkhya was de facto atheistic; being theistic, Yoga was concerned with physical and spiritual practices Mìmāmsā deals with ritual and its meanings. From all dārșanas Vedanta was theistic and offered a broad possibilities for reflections on spiritual themes and also for thinking on ethical, social and cultural themes. The choice of Vedanta permitted to hold a succession to tradition - in spite of independent position of each thinker. No one of Bengal thinkers belongs to orthodox schools, transmittable by traditional method from a teacher to pupil. The distance from orthodoxy allowed to create new version of ancient Vedanta.

\section{GENESIS OF NEO-VEDANTISM: RAMMOHUN ROY}

W. Halbfass remembers, that '...the role of the Vedanta as a source of authority was ambivalent in Bengal in the period around 1800 . The Navyanyāya was predominant in scholastic teaching, and the systematic study of the Vedanta did not play a conspicuous role', but Rammohun had special genuine selfunderstanding as 'Vedantin' [9, P.214]: he was educated in Benares, estimated center of the Vedanta learning. After settling in Calcutta, Rammohun had published 'Vedantic' works: Vedanta Grantha, Vedantasara (in Bengali, 1815), Abridgement of Vedanta (in English, 1816), translations of Upanișads - Isa, Kena (both in 1816), Mundaka and Katha (1817) into English and Bengali. His interpretation of Vedanta laid in the foundation not only of his religious ontology, but of anthropology, ethics and partially social thought.

His first intention was to appeal to Vedas authority for an explanation of true essence of Hinduism - as Rammohun himself understood its spirit - it was intended for his coreligionists. Rammohun presented Badarayana's Vedantasutra as "The Resolution of all the Vedas" because of full body of Vedic literature 'written in the most elevated and metaphorical style' [10, P.261]. While at present Hindus "firmly believe in the real existence of innumerable gods and goddesses", their idolatry 'destroys the texture of society' and moral consciousness [10, P.262-263], Rammohun calls to read the Scriptures for contemplate with and worship to One omnipresent and omnipotent God of Vedas. Thus, the philosopher reduced all Vedic complex to early Upanișads with its conception of Brahman, which integrated into Vedanta-sutra. Rendering basic content of Badarayana's Vedanta, Rammohun created key ideas of new version of Vedanta - neither Advaitic (absolute monism), nor Viśișțādvaitic (qualified Non-Dualism).

Though 'the accurate and positive knowledge of the Supreme Being (Brahman - T.S.) is not within the boundary of comprehension' [10, P.264], Rammohun gives Him both apophatic and cataphatic definitions, and creates synthetic Vedanta. Apophatic definition appears from Upanișadic phrases ('bears no figure nor form', 'His existence had no cause' etc.) [10, P.268], but cataphatic ones belongs to Rammohun. He describes Brahman as Creator, Preserver and Destroyer of the Universe, and also as Author, Creator of Nature, Lord of Universe and the Truth (Om tat Sat). This notion of Brahman is the foundation of 'the Creed' of NeoVedantism.

Rammohun postulates the combination of faith in one God with knowledge of Him. The knowledge is attainable both apophatically - through enumeration of 'not this' ('na iti, na iti'), and through comprehension of His Creation: 'We see the multifarious, wonderful universe, as well as the birth, existence, and annihilation of its different parts; hence, we naturally infer the existence of a Being who regulates the whole, and call him the Supreme' [10, P.264]. The organic part of Rammohun's Vedanta is rejection of rituals, ceremonies, food rules etc.; these must be replaced by 'hearing and thinking of Him', 'practice of devotion', adoration and 'command over our passions and over the external senses of the body and good acts' [10, P.271]. Vedantic traditional jnāna (knowledge) and bhakti (love) are united with moral life and ethics. The later can be explained by Christian influences on Rammohun.

These key foundation Rammohun develops in his interpretation of Upanișads. The introductory parts to ones English translations content his Vedantic ideas.

1) Brahman is 'the sole Regulator of the Universe', invisible 'Intellectual principle... entirely distinct from matter and its affections'. And 'nothing is absent from God, and nothing bears real existence except by the volition of God, whose existence is the sole support of the conceived existence of the universe' [7, P.63, 21, 45, 69]. This in the basic of monism philosophy, monotheism in reform practice because of rejection of all pantheon of Hindu gods. The high belief in unity of God Rammohun postulates as the sole path to eternal beatitude for each man and all humanity [7, P.67].

2) Human soul is a part of the Supreme Being, who is 'the sole Origin of individual intellect' [7, P.45]. Rammohun does not say on Brahman-atman identity; his understanding of human is more definitive. He says on limited physical powers of man, while 'ratio and moral faculties' embrace 'a wide sphere of action, and possessing a capability of almost boundless improvement' [7, P.73]. Idea of improvement is one 
of most important for Rammohun, and he adds the path of ethical life to traditional jnāna and bhakti path to God 'rendering benefit to his fellow-creatures' for gaining happiness and final beatitude [7, P.73].

3) The essential characteristics of God are the goodness and mercy. The Supreme Being is 'to whom the motives of our actions and secrets of our hearts are well-known' [7, P.37, 46]. Therefore, from imperative of knowledge of God come moral principles of human life in the world. Rammohun's monotheism and monism is ethical: God have defined the good goals for his creations, these ones suppose religious service to Him in high forms and love and thinking on Him, righteous live and good service to fellows. There are two groups of human duties: 'the rational performance of your duty to your sole Creator, and to your fellow creatures, and also to pay true respect to those who think and act righteously' [7, P.71]. This ideas inspire Rammohun to fight with polytheism which replace good by evils - in idea of strict following to ritual and caste rules, as well as traditional morality which held 'performance of a few idle ceremonies' 'as a sufficient atonement for all those crimes' - murder, theft, perjury etc. but punished the least aberration from diet and other caste rules. Rammohun says on the true sin as 'evil thoughts proceeding from the heart, quite unconnected with .observances as to diet and other matters of form' [7, P.46]. Consequently, Rammohun claims compassion, humility and mercy in human relations.

Thus, Rammohun had created the foundations of NeoVedanta which essential novelty was in grounding of ethical nature of Brahman as well as anthropological ideas such as value of human being as God's creation and high estimation of his earthly life. Besides, Rammohun in his Vedanta had created the ethics of religious humanism, which overcomes the alienation of high content of earthly life and opens the path to freedom of person.

\section{DEVELOPMENT OF NEO-VEDANTISM}

Rammohun's religious-philosophical considerations resulted in basic ideas became the foundation of his 'Brahmo Samaj' (1828, 'Society of [believers in] One God'). Its leader Devendranath Tagore (1818-1905) continued the reflections on Vedanta. Based on Upanișads he said on Brahman as eternal, 'formless, the very essence of intelligence, omnipresent, beyond all thought or speech' [11, P.20]. God is origin of good, knowledge, wisdom, life, energy; eternal joy etc.; through deep introspection human comes to knowledge of Atman/Self as his own spiritual essence. Devendranath Tagore desired 'preach the Brahma Dharma as based upon the Vedanta', understood as Upanișads, 'the crowning point and essence of all the Vedas' [11, P.40].

Devendranath was strict follower of Rammohun in the rejection of any forms of polytheism and idolatry. After deep learning of Vedic Samhitas, he had rejected, firstly, Vedas because of sanctioning karma-kanda (rituals) and, secondly, the Upanișads as wide collections of texts from ancient to precolonicl periods. The 'thorny tangle of Upanishads' did not permit to 'lay the foundation of the Brahma Dharma' [11, P.74]. Devendranath's strong position was the differentiation of Brahman as an object of devotion and the believer as subject of one: 'He is the worshipful, I am His worshipper ; He is my Master, I am His servant ; He is my Father, I am His son. This was my guiding principle' $[11$, P.23]. Thence, he rejected Brahman-atman identity ('I am He' and 'Thou art That') in Upanișads as well as Śankara's ādvaita. He propose to follow spiritual revelation, therefore, 'Brahma reigned in the pure heart alone. The pure, unsophisticated heart was the seat of Brahmaism. We could accept those texts only of the Upanishads which accorded with that heart' [11, P.75]. Devendranath refused from Śankkara's māyā, because both God and universe are real as absolute and relative truths [11, P.85]. As a result, he had created Brahmi- Upanișad and a book of moral precepts ('Brahma Dharma Grantha') based predominantly on Bhagavadgita and Manu [11, P.80-84].

Devendranath's novation was in liberation from formal authorities of Scriptures and classical tracts and commentaries for free contemplation and realization of truth. His Vedanta is Viśiștādvaitic: Brahman is before all Creator of the world and a human being, who is in active interactions with Him. Brahmo Vedantism was imbibed by Devendranath's son Rabindranath Tagore in his poetry and philosophical works.

Viśiștāanvaitic approach was very attractive for traditional religious consciousness, which concentrated upon God-human relations. The approach became the core for development of specific 'synthetic' Vedanta integrated its different schools into dialectic unity.

The integration of schools was postulated and explained by Bengal mystic, saint and inspired preacher Ramakrishna Paramahamsa (Gadadhar Chattopadhyay, 1836-1886). A son of poor village Brahmin, he had experienced in samadhi (ecstasy) different religious practice of Hinduism and other religions (Christianity, Islam and Buddhism) and preached the essential unity of all religions. Punjab Brahmin Totapuri had initiated him in ādvaita-sadhana - mystical Brahman-atman identity. Ramakrishna's interpretation of Vedanta bases on understanding: 'Brahman alone is Reality, and all else is unreal' and 'the Rishis of olden times renounced everything and then contemplated Satchidananda, the Indivisible Brahman' [12, Vol. I, P.116, 254]. The preacher describes Absolute as unity of dialectical oppositions - transcendent and immanent, having form and formless, impersonal and personal. Ramakrishna's universal monism of advaita combined with idea of reality of the world, which is result of lila (God's play). The world is real, being incarnation of High reality; simultaneously, the one is unreal, when human realizes his own atman as a child of God, who appears in human soul more than else.

Ramakrishna represents three Vedanta schools as successive stages of rational reflections of a believer in God. These ones are equally true, because human spiritual path is from simple stages of realization of God to complicated stages. Dvaita-vedanta dualism suits for human who is in first stages of knowledge: Brahman is personal God (Ishwara) and jiva (soul) is not identical with Him. By Ramakrishna's words, 'I'm Thine, yet Thou art not mine' and an example: 'The waves belohgs to ocean, and never ocean to the waves' [12, Vol. II, P.232]. Viśișțādvaita also is reconciled with ādvaita: 'I accept His māyā and also his various appearances; I accept the 
diversity created by māyā as also the non-dual Principle devoid of all diversity' [12, Vol. I, P.332]. It is second stage of Vedanta - qualified non-dualism. Ādvaita's identity atman with Brahman is natural for human-brāhmojnāni who is able to go into samadhi: 'Reaching the seventh plane, the mind is annihilated... What he feels, then cannot be described in words' [12, Vol. I, P.200]. The third stage - àdvaita is highest stage of realization of God, who is 'pure mind, pure intelligence, and pure Atman are one and the same' [12, Vol. I, P.546].

Openly synthesized three branches of Vedanta into one, Ramakrishna had formed the core for Neo-Vedanta system, developed by his famous pupil, philosopher Swami Vivekananda (Narendranath Dutta, 1861-1902). He turned Vedanta into universal, all-embraced and literally "omnipresent" philosophy, which could be found in each religion, philosophy and culture as its foundation and meaning.

Vedanta for Vivekananda is the end of Vedas and monistic philosophical school, which 'In the course of time the Vedanta prevailed, and all the various sects of India that now exist can be referred to one or other of its schools' [13, Vol. II, P.239]. Vivekananda represents Vedanta as integral and universal knowledge of Indian civilization - both ancient and contemporary - which embraces all dārșanas (including nāstika Buddhism and Jainism) and organically unites three branches of classical Vedanta [13, Vol. II, P.239-259] as stages of Godknowing. The philosopher repeats and develops three key ideas by Rammohun Roy: Brahman as Supreme Being, atman as part of him in human soul and moral character of God.

The concept of unity of Universe Vivekananda bases on ādvaita: One free (without cause) eternal Absolute (nirgūnaBrahman) determines physical, spiritual and moral unity of the world. He 'has become the universe by coming through time, space, and causation', and 'the degeneration of the Absolute into the phenomenal, and not before; that our will, our desire and all these things always come after that'. Time, space, and causation are God's māyā in which appears changes composed of the universe [13, Vol. II, P.130-136]. The philosopher concludes: 'The Vedanta says there is nothing that is not God' [13, Vol. II, P.321]. The rejection of idea of illusion of the world issued the affirmation of high meaning of social, historical and cultural being of human.

Vivekananda solves key Neo-Vedanta problem of human through identifying him with God: 'The body is not the Real Man, neither is the mind, for the mind waxes and wanes. It is the Spirit beyond, which alone can live for ever. ... So this infinite Unit is unchangeable, immovable, absolute, and this is the Real Man. Our reality, therefore, consists in the Universal and not in the limited. These are old delusions, however comfortable they are, to think that we are little limited beings, constantly changing. People are frightened when they are told that they are Universal Being, everywhere present' [13, Vol. II, P.79-80]. Human is potentially divine, and meaning of his existence is in realizing and appearance of Divinity, his real nature, and in gaining freedom in earthly life. It determinates the greatness of human in the world - really, new idea, which is main leading motive of Vivekananda's Vedanta. Misery and dependence of human in the world prevent him to strive for happiness and freedom. The cause of misery philosopher saw in absence of knowledge: 'The misery that we suffer comes from ignorance, from non-discrimination between the real and the unreal. We all take the bad for the good, the dream for the reality. Soul is the only reality, and we have forgotten it' [13, Vol. I, P.287].

Discrimination (viveka) is the method of rational knowledge of absolute truth for absolute happiness and freedom. According to Vivekananda, man freed in earthly life (jīvanmūkta) is not ascetic but human ready for service for other people. Another method to gain knowledge is ethical behavior, which Vivekananda builds on altruistic imperative. He says: 'Ethics always says, 'Not I, but thou.' Its motto is, "Not self, but non-self." The vain ideas of individualism, to which man clings when he is trying to find that Infinite Power or that Infinite Pleasure through the senses, have to be given up - say the laws of ethics. You have to put yourself last, and others before you. ... Ethics says, "I must hold myself last." Thus, all codes of ethics are based upon this renunciation' [13, Vol. II, P. 62-63]. The moral foundation of path to freedom combines from 'universal moral norms' - love, mercy, good, rightness and non-violence.

In Vivekananda's Vedanta are united two dārșanas which were not pair-schools in classical period: Vedanta and Yoga. In new-made pair the first is philosophical theory of the universe, foundation of Indian spiritual tradition and culture, and Yoga is practical path to freedom. If Ramakrishna have proposed three marga/yoga for modern people - karma (action, work), jnāna and bhakti, Vivekananda adds raja-yoga (classical yoga from Patanjali system) of psycho-physical trainings. In his famous 'Four Yogas' (1893-1896) philosopher places into foreground karma-yoga as path of disinterested active work. This yoga suits for all people including agnostics and atheists. The easiest yoga is bhakti, the way of love to God and all the world, and jnāna is most difficult. According to Vivekananda, all yogas confirm universal Vedantic truth and permit to develop of both human and society.

Neo-Vedanta laid down in his social-philosophical views, in which he says on social aspects of freedom. Briefly, all human groups, strata, communities and societies are aspiring to freedom, and the aspiration is embodied in striving for a progress, to command over inner and outer nature, even in a struggle, conflicts and wars. That's why, philosopher proposes fight against social evils - traditional and modern - and active social service for development of society.

Swami Vivekananda's Vedanta system can be called complex philosophy, united ontology, epistemology, anthropology, ethics and social philosophy. His Neo-Vedanta became the starting-point for development of Indian philosophy in XX century.

\section{CONCLUSION}

Neo-Vedantism presents the synthetic phenomena in Modern Indian philosophy. Bengal thinkers treat Vedanta in non-dogmatic and free manner. From the one hand, NeoVedanta appeared and developed as the continuation of influential theistic system of classical philosophy - the most suitable to Modern needs in cultural and social spheres. The 
diversity of schools in classical Vedanta is unessential for new thinkers, because they turned to the spirit of idealistic monism opposed to the letter of religious practice and orthodox thinking. Also it was the break with scholastics of other schools which did not permit to think on urgent philosophical and cultural question. From the other hand, Neo-Vedanta was re-built based on humanistic approach: the key theme of it became human being-in-world as ethically correlated with Brahman. The approach turns to ethical and social problems - consequently, all New-Vedantist thinkers were creators of Indian social thought. Creative transformation of Vedanta permitted to integrate Modern ideas into native tradition and simultaneously to save the spirit of Indian thinking in Modernity.

\section{REFERENCES}

[1] British Paramountcy and Indian Renaissance. Ed. by R.Ch. Majumdar. 2 vols. Bombay: Bharatiya Vidya Bhavan. 1963-1965.

[2] K.N. Panikkar, Colonialism, Culture and Resistance. New Delhi: Oxford University Press, 2007.

[3] Subrata Dasgupta, Awakening: the Story of the Bengal Renaissance. Noida: Random house Publishers, 2010.

[4] Subrata Dasgupta, The Bengal Renaissance: Identity and Creativity from Rammohun Roy to Rabindranath Tagore. Delhi: Permanent Black, 2012.

[5] D. Kopf, British Orientalism and Bengal Renaissance. Berkeley: University of California Press, 1969.

[6] Tatiana G. Skorokhodova, The Bengal Renaissance: Essays on History of Socio-cultural Synthesis in Modern Indian Philosophical Thought. St.-Petersburg: St. Petersburg Centre for Oriental Studies Publishers, 2008. (In Russian).

[7] Raja Rammohun Roy, The English Works / Ed. by J.C. Ghose. In 4 vols. New Delhi: Cosmo, 1982. Vol.I.

[8] S.D. Collet, The Life and Letters of Raja Rammohun Roy. $3^{\text {td }}$ ed. Calcutta: Sadharan Brahmo Samaj, 1962.

[9] W. Halbfass, India and Europe. An Essay of Philosophical Understanding. Albany, SUNY Press 1988.

[10] Raja Rammohun Roy, Selected Works. New Delhi: Government of India. Ministry of Information and Broadcasting, 1977.

[11] Tagore Devendranath, The Autobiography. Transl. from Original Bengali by S. Tagore and I. Devi. Calcutta: S.C. Lahiri \& Co., 1909.

[12] Swami Bhuteshananda, Sri Ramakrishna and His Gospel. In 5 vols. Kolkata, 2006-2007.

[13] Swami Vivekananda, Complete Works. 12 th ed. 9 vols. Almora: Advaita Ashrama. 1998-2002. 